Article

\title{
Collaborative Governance in Tourism: Empirical Insights into a Community-Oriented Destination
}

\author{
Bernhard Fabian Bichler *(1) and Magdalena Lösch \\ Department of Strategic Management, Marketing and Tourism, Faculty of Business and Management, \\ University of Innsbruck, Karl-Rahner-Platz 3, 6020 Innsbruck, Austria; magdalena.loesch@student.uibk.ac.at \\ * Correspondence: bernhard.bichler@uibk.ac.at; Tel.: +43-512-9565
}

Received: 23 October 2019; Accepted: 21 November 2019; Published: 26 November 2019

\begin{abstract}
Governance offers valuable guidelines to steer and direct destinations. Recent tourism governance research has explored the role of multiple actors in governing destinations but has not comprehensively investigated the underlying collaborative governance (CG) processes such as face-to-face dialogue, trust-building, shared understanding, or supporting factors such as institutional setting or leadership. The objectives of this paper are to determine the drivers and barriers of CG in a community-oriented destination in South Tyrol (Italy). This aims to reveal the processes that drive collaboration between stakeholders. For this reason, the paper builds on a qualitative case study with 20 semi-structured interviews with key informants. The results highlight that destination leadership is an essential driver of CG. However, several barriers to CG emerged. First, the findings show that institutional transformation led to a lack of trust and increased insecurity. Second, the inclusion of salient actors such as residents in the decision-making and implementation phase is scarce. Third, our findings highlight that a shared understanding of future development directions is missing between stakeholders. The contribution of this paper is a refined assessment of CG in tourism with special attention to the role of leadership and institutional settings. The derived implications target the role of leadership to foster the development of a shared understanding and to embark on a collaborative learning process that provides visible and tangible outcomes in turbulent times.
\end{abstract}

Keywords: collaborative governance; governance; collaboration; stakeholder engagement; transition; tourism destination

\section{Introduction}

The governance of destinations, which are strongly shaped by touristic activities, is becoming an increasingly important topic [1-3]. Research has investigated the principles of tourism governance under varying settings [4,5]: At an institutional level, research has concentrated on the role of governance for economic performance [6,7], but recently social and environmental aspects of governance have received increased attention [8,9]. Previous studies have reported that tourism governance needs to adopt a holistic understanding of social factors such as citizen participation and collaboration among stakeholders $[9,10]$. At the organization level, it was shown that networks significantly contribute to tourism governance [11-13] and that collaboration and cooperation represent an essential aspect of tourism destinations [14]. In particular, recently increased interest has occurred for collaborative, community-oriented tourism governance models [14-16]. Nevertheless, a large body of governance literature has concentrated on economic indicators highlighting the need for more research on the social factors that shape tourism governance. Furthermore, collaborative processes in tourism have been investigated without paying attention to underlying and supporting factors $[17,18]$. The objective of this paper is to provide an integrated assessment of processes that drive or hinder collaborative 
governance (CG). The aim is to determine the factors that affect $C G$ in the tourism context. For this reason, we use the framework by Ansell and Gash [19], which incorporates collaborative processes such as trust-building, commitment to processes, but also supporting factors such as leadership and institutional design.

The tourism industry is understood as a fragmented industry with an amalgamation of interdependent service providers [20]. Furthermore, formal and informal governance arrangements interact on the destination level. While tourism and hospitality businesses are often driven by socially informed governance due to family-related dynamics and regional embeddedness [21], destination management organizations are characterized by formal governance arrangements [22]. The governance setting of destinations has often followed phases of initiating tourism, boosting tourism, and reacting to arising issues [23]. Additionally, the initial focus of governance as a government issue has changed to transform destinations to be more integrative in order to tackle issues of declining support for tourism $[9,24]$. The success of CG relies on "whether the members of a collaborative network are able to develop new processes that will lead to new ways of working, new structural arrangements and integration of the members into a new whole, which will lead to the accomplishment of innovative solutions" [25] (p. 579).

The case study of the destination MeranerLand (South Tyrol, Italy) offers a particularly interesting setting because the bodies responsible for managing tourism changed on a large scale. Twenty interviews with key informants from four major stakeholder groups were conducted to generate in-depth insights into the drivers and barriers of CG. First, this paper highlights the role of institutional settings [26] and leadership [27] to achieve collaborative outcomes. Second, it provides an integrated assessment of drivers and barriers of CG. Implications target collaborative learning processes to improve the shared understanding of development objectives. The first part of the paper provides a theoretical overview and literature review of CG in tourism. The second part introduces the research design and procedure for data analysis. The third part highlights the results and provides a discussion of CG in tourism. Lastly, part four provides the conclusions, implications, and several directions for future research.

\section{Theory Section and Literature Review}

\subsection{Tourism Governance}

Governance aims to organize and coordinate destinations [28]. Presenza, Abbate, and Micera [29] summarized that the aim of governance is to "coordinate local stakeholders to design and develop destinations ( . . ) fostering different valuable forms of commitments, synergies and collaborations between public/private actors and assisting policy-makers to implement sustainable development (... )" [29] (p. 480). Governance is about structures and processes and aims to understand how and why different components such as institutional design, personal relationships, and networks play together [27]. Previous research showed that "good governance" addresses several dimensions such as participation, legitimacy, transparency, and efficiency [2]. In this context, good governance can be achieved if all actors work together and manage to share power, expertise, and resources between public and private actors [30,31]. However, tourism governance frequently focused on business and government interests rather than including multiple stakeholders $[9,32]$.

The collaboration between actors is of utmost importance for good governance because tourism is known to represent a fragmented industry with diverse actors that jointly provide tourism services [20]. In this context, managing relationships with stakeholders is becoming imperative in order to ensure legitimacy and acceptance [33,34]. However, these relationships can be costly and time-consuming when extensive and various barriers to engage with stakeholders exist [34,35]. In order to assess these drivers and barriers, we shed more light on the underlying processes of CG [19]. 


\subsection{Collaborative Governance in Tourism}

CG is a major research stream in the public administration literature $[19,36]$, however less is written about CG in tourism. A systematic assessment [37] with the keywords "collaborative governance" and "tourism" (title, keywords, and abstracts) in the Web of Science (Core Collection) and EBSCOhost (Business source premier) databases resulted in 10 final publications that address CG in tourism (Table 1).

Table 1. Overview of collaborative governance (CG) literature with a tourism background.

\begin{tabular}{|c|c|c|c|}
\hline Author and Year & Method & Level & Findings \\
\hline Vignieri (2019) [38] & $\begin{array}{c}\text { Mixed } \\
\text { (Simulation) }\end{array}$ & Local & $\begin{array}{l}\text { innovative interactive learning environment is } \\
\text { used to highlight the role of governance that fosters } \\
\text { coordination in order to manage shared resources } \\
\text { village community receives limited tourism }\end{array}$ \\
\hline Keyim (2017) [14] & $\begin{array}{l}\text { Qualitative } \\
\text { (Interviews) }\end{array}$ & Local & $\begin{array}{l}\text { benefits but fair and effective community tourism } \\
\text { governance approach may bring positive } \\
\text { socio-economic benefits }\end{array}$ \\
\hline $\begin{array}{l}\text { Gyimóthy and } \\
\text { Meged (2018) [39] }\end{array}$ & $\begin{array}{c}\text { Qualitative } \\
\text { (Ethnography) }\end{array}$ & Regional & $\begin{array}{l}\text { three domains of CG, namely governance of affect, } \\
\text { governance of ownership and governance of } \\
\text { exchange are identified }\end{array}$ \\
\hline $\begin{array}{c}\text { Dragouni and } \\
\text { Fouseki (2018) [40] }\end{array}$ & $\begin{array}{l}\text { Quantitative } \\
\text { (Regression) }\end{array}$ & Regional & $\begin{array}{c}\text { intention to participate in heritage tourism } \\
\text { development is mostly influenced by community } \\
\text { ideals and stronger for members with high } \\
\text { place attachment }\end{array}$ \\
\hline Selin (2017) [17] & $\begin{array}{l}\text { Qualitative } \\
\text { (Case Study) }\end{array}$ & Regional & $\begin{array}{c}\text { leadership teams' roles and capabilities act as a } \\
\text { backbone for sustainable regional development in } \\
\text { an integrative way beyond } \\
\text { public/private institutions }\end{array}$ \\
\hline Keyim (2016) [18] & $\begin{array}{c}\text { Mixed } \\
\text { (Survey, } \\
\text { Questionnaire, } \\
\text { Secondary data) }\end{array}$ & Regional & $\begin{array}{l}\text { local community lacks share of socio-economic } \\
\text { benefits of tourism and CG is needed to foster } \\
\text { cooperation and bottom-up developments }\end{array}$ \\
\hline $\begin{array}{l}\text { Charlie, King, and } \\
\text { Pearlman (2013) [41] }\end{array}$ & $\begin{array}{l}\text { Qualitative } \\
\text { (Case Study) }\end{array}$ & Regional & $\begin{array}{l}\text { revised conceptual framework for analysis of } \\
\text { environmental governance networks in small } \\
\text { island destinations }\end{array}$ \\
\hline Zeppel (2012) [42] & $\begin{array}{c}\text { Qualitative } \\
\text { (Secondary data) }\end{array}$ & National & $\begin{array}{l}\text { state and territory tourism agencies provide } \\
\text { resources for climate change mitigation. CG of } \\
\text { climate is better developed in states with climate } \\
\text { change policies, vulnerable destinations, or } \\
\text { dependency on long-haul travelers }\end{array}$ \\
\hline Robertson (2011) [43] & $\begin{array}{l}\text { Qualitative } \\
\text { (Case Study) }\end{array}$ & Regional & $\begin{array}{l}\text { networks have the potential to create benefits and } \\
\text { achieve CG, but much depends on the role of, e.g., } \\
\text { public managers and the involvement of } \\
\text { government agencies. }\end{array}$ \\
\hline $\begin{array}{l}\text { Erkuş-Öztürk and } \\
\text { Eraydin (2010) [8] }\end{array}$ & $\begin{array}{l}\text { Mixed } \\
\text { (Survey, } \\
\text { Interviews) }\end{array}$ & Regional & $\begin{array}{c}\text { importance of CG networks and different scales of } \\
\text { networks and organization building for sustainable } \\
\text { tourism development }\end{array}$ \\
\hline
\end{tabular}

The literature review (Table 1) shows that the CG understanding from the public administration literature has not fully disseminated to the tourism field. From a public administration literature perspective, Robertson [43] introduced the CG perspective [19] to the tourism context. His conclusions emphasize cooperation, coordination, and collaboration as critical success factors for collaborative governance and highlight the role of public managers for success. Nevertheless, questions remain because the institutional design differs in other destinations and other actors might be more salient than public managers. Keyim [18] argues that CG has different interpretations and distinguished between, e.g., the tourism, rural studies, and public administrations context. It is concluded that more research is necessary on "the role of NGOs and similar civil society organizations" in the case study destination [18] (p. 547). This highlights the need for more research on the impact of stakeholder configurations on collaborative governance, which is particularly relevant because previous collaborative governance contributions have not addressed the context of community-oriented destinations with established 
management bodies such as destination management organizations (DMOs) (Table 1). Selin [17] highlighted the importance of leadership for collaborative approaches and also used the model by Ansell and Gash [19]. Drawing on the concept of backbone organizations [44], it was found that backbone leadership adds to the success of coalitions [17]. It appears promising to explore varying leadership roles in established, community-oriented destinations in order to show the varying roles of different stakeholders. Additionally, in a recent review on tourism governance, Bichler [9] (p. 10) called for more research on the implications of varying governance settings and to account for the multiple roles actors (e.g., destination managers and policymakers). We argue that the structured and empirically driven CG model by Ansell and Gash [19] provides a valuable guiding framework for the further analysis of governance, entrepreneurship, and institutional settings.

CG aims to bridge public and private stakeholders into a consensus-oriented decision-making process [19]. The collaborative framework builds on a set of starting conditions that include power-resource asymmetries, incentives for and constraints of participation, and prehistory of cooperation or conflict (Figure 1). Starting conditions such as power [45,46], participation [47-49], and conflicts or cooperation have been important topics in tourism research $[50,51]$.

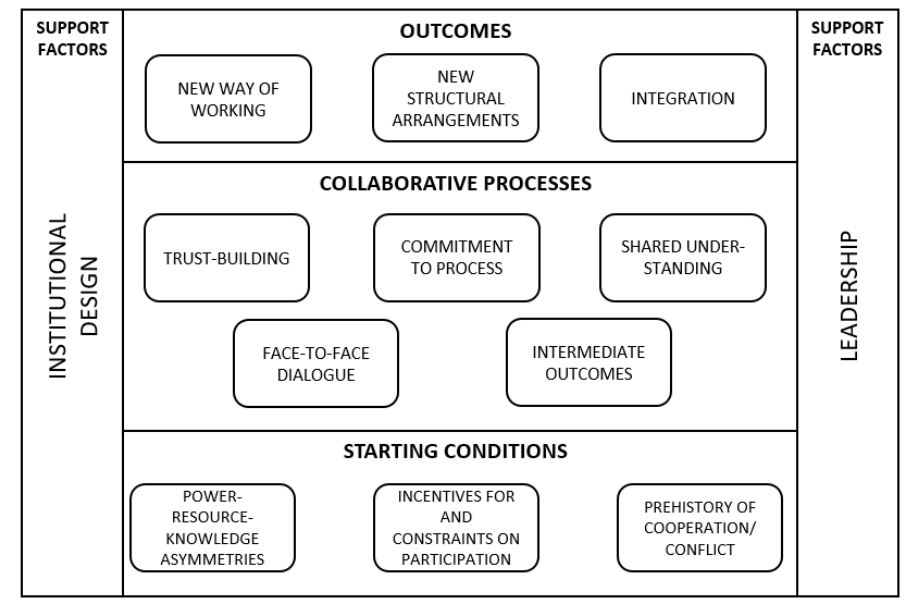

Figure 1. Model of collaborative governance, adapted from Ansell and Gash, [19] and Mandell and Keast, [25].

Central to the model (Figure 1) are the collaborative processes that include trust-building, commitment to process, shared understanding of strategic goals and beliefs, intermediate outcomes, and face-to-face dialogue [19]. Additionally, leadership and institutional design affect the capacity to achieve CG. For example, leadership was recognized as a critical factor across disciplines $[27,35,52]$ and previous research showed that leadership in tourism is often shared among a group of individuals $[17,52]$. Thus, leaders such as local entrepreneurs and representatives that influence core services, strategic orientation, and innovation capability [53] have a central role as they interact will all spheres of tourists, entrepreneurs, public bodies, and the local communities. The y shape the environment, share common interests, and have a commitment to influence a field of practice or policy [54]. Leaders share responsibilities and have a crucial position in managing and providing opportunities for engagement (e.g., determining how information is shared, how policy and strategy are set, and what programs/initiatives are implemented). Additionally, research showed that networks support leaders in finding common ground around issues they care, mobilize support, and influence policy and the allocation of resources $[54,55]$. A network perspective is promising because it links leaders who share common interests and who have the commitment to influence practice and policy $[24,56]$. Networks help to bundle resources, reach consensus and exert influence [24,27].

Ansell and Gash [19] recognized that the institutional design affects collaborative processes. While Ansell and Gash [19] perceived the institutional design as the basic protocols and ground rules for collaboration [18], the understanding of institutional design in the tourism context is much 
broader [57]. Important institutions are DMOs, regional tourism organizations (RTOs), national tourism organizations (NTOs), and local/regional/national public authorities. According to Ansell and Gash [19], institutions should be open and inclusive, enable and seek participation, and show clear ground rules and process transparency. The withdrawal and transformation of institutions and changed responsibilities can challenge these principles [58,59]. Previous research found that open innovation platforms, either analog or digital, can be used to improve the participatory design of institutions $[60,61]$.

\section{Materials and Methods}

A qualitative case study is used to shed more light on the multiple underlying phenomena that shape CG [62,63]. The qualitative approach is helpful, in order to understand the complexities of a tourism destination network [64]. In this context, the case study allows a deeper understanding of the researched phenomena [62] and O'Mahoney and Vincent [65] noted that "while numbers count, they are meaningless without a broader explanatory framework" [65] (p. 4). This framework is provided by the concrete case of the MeranerLand, which provides context and depth for the interpretation of results [66]. Furthermore, case studies are well situated for exploratory research [67].

The research setting is the destination MeranerLand in South Tyrol, Italy (Figure 2), which accounted for more than 7 million overnight stays and over 1.5 million arrivals in 2017 [68]. Merano, the principal town in the destination, is known as a spa and cultural destination and accounted for over 1.1 million overnight stays in 2017 [68]. Furthermore, the MeranerLand offers options for nature-based activities in the surrounding valleys. The area has a rich heritage due to bilingualism and the status as an autonomous region in Italy. Recently, South Tyrol was subject to changing governance settings: In 2006, the 15 tourism associations around Merano launched a destination marketing organization (DMO), with a regional tourism association (RTO) on top. The top-tier organization was known as "South Tyrol Marketing Association" (SMG). In 2015, the government decided to establish a central agency called "Innovation Development Marketing" (IDM) and incorporated the SMG to foster innovations, product developments, communication, and marketing across different industries in South Tyrol [69]. In 2018, the existing DMOs of South Tyrol were integrated into the IDM South Tyrol to target the market with three strategic business units (west, middle, and east). The se business units focus on topics such as ski and winter in order to improve international visibility and departed from promoting independent destination brands [70]. Nowadays, the former DMO MeranerLand is represented by the IDM West, but the brand "MeranerLand" persists [71]. This institutional change, which affected the governance structure, makes South Tyrol (Italy) a particularly interesting case to explore CG.

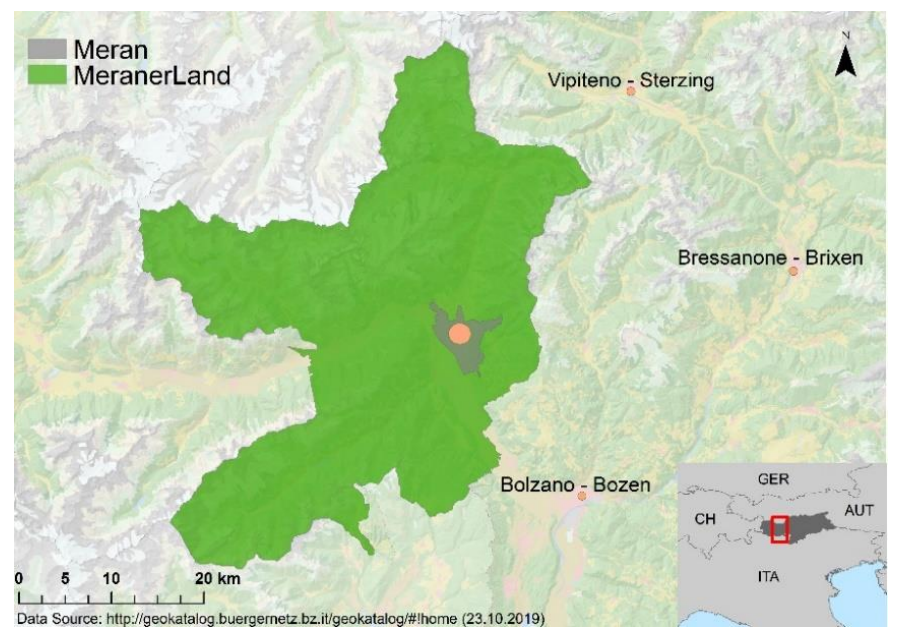

Figure 2. Overview map of the MeranerLand. 


\subsection{Sample}

This case study builds on 20 semi-structured interviews with key informants, interviewing multiple actors (Table 1) to gather in-depth insights into the processes and underlying conditions that shape CG in a tourism destination. The researchers had no existing relationships with the interviewees but personal connections were used to contact the first interviewees [72]. The y were selected in a two-step approach: First, non-probability, information-oriented selection that aims at maximizing information based on expectations about the content was used [66]. Second, a snowball sampling approach was used, asking interviewees to identify other potential informants [73]. This process led to 20 interviews in the destination. Table 1 provides several key characteristics of the interviewees.

The interviewees (Table 2) belong to four major stakeholder groups (local tourism associations, destination management organizations, entrepreneurs, and local public bodies). The oldest interviewee was 78 years old and the youngest 32 years old, with a majority of male interviewees (70\%). After 20 interviews, saturation was reached as nothing new or unpredictable emerged [74].

Table 2. Sample overview.

\begin{tabular}{lccc}
\hline Stakeholder Group & ID & Gender & Position \\
\hline Local TA level & & & Director TA \\
& 1 & Female & Director TA \\
& 2 & Male & Director TA \\
& 3 & Male & Director TA \\
& 4 & Female & \\
DMO level & 5 & Male & Hotelier and Innkeeper Association \\
& 6 & Male & Director DMU \\
& 7 & Female & Product Management DMU \\
& 8 & Male & Former Director DMO \\
& 9 & Male & Former Director DMU \\
Entrepreneurial level & 10 & Male & Hotelier and Innkeeper Association \\
& 11 & Male & Hotelier \\
& 12 & Male & Hotelier/Territory Commissioner \\
& 13 & Male & Hotelier \\
& 14 & Male & Hotelier/Entrepreneur \\
& 15 & Female & Hotelier \\
& 18 & Male & Event Organiser \\
& 16 & Female & Municipality Councillor \\
& 17 & Male & Mayor \\
& 19 & Male & Director Infrastructure \\
& 20 & Female & Director Infrastructure \\
\hline
\end{tabular}

Note: $\mathrm{TA}=$ tourism association. $\mathrm{DMO}=$ destination management organization.

The semi-guided interviews were conducted in German, lasted on average for 40 minutes, and were recorded at the workplace from January to March 2019. All interviewees stay anonymous as confidentiality was ensured. Based on the literature review, the research team developed an interview guideline that addressed the key questions around antecedents, processes, and outcomes of governance (Table 3). Two researchers translated all text units in order to ensure accuracy. 
Table 3. Interview guideline.

\begin{tabular}{|c|c|}
\hline Questions & Literature \\
\hline $\begin{array}{l}\text { In general, what is the role of leaders in a destination? What was your role in } \\
\text { this context? How would you describe the role of networks? }\end{array}$ & Volgger and Pechlaner [1] \\
\hline $\begin{array}{l}\text { What stakeholders are important for your decisions? How do you engage with } \\
\text { your stakeholders? Whom do you consult before taking important decisions? } \\
\text { What outcomes did you observe from engaging with your stakeholders? }\end{array}$ & Ansell and Gash [19] \\
\hline $\begin{array}{l}\text { What are future development options? Can you describe how the constellation } \\
\text { of actors will change in the future? }\end{array}$ & $\begin{array}{l}\text { Beritelli [50]; Tuohino and } \\
\text { Kuno [75] }\end{array}$ \\
\hline
\end{tabular}

\subsection{Data Analysis}

For data analysis, the template analysis approach is used [76,77]. Central to template analysis is the development of a template [78], which involves the construction of an initial coding template with a priori codes. This initial template is applied to a subset of the data, refined and revised with inductive codes until it "captures as full a picture of the analyst's understanding as possible" [78] (p. 219). The qualitative data analysis software MAXQDA supported data analysis. This software allowed operationalizing the template, assigning codes to text, and performing qualitative/quantitative analysis. An iterative coding process aimed to identify overarching themes, which King [78] (p. 200) defined as "recurrent and distinctive features of participants' accounts, characterizing particular perceptions and/or experiences, which the researcher sees as relevant to the research question". Major benefits of template analysis include a structured but also flexible approach to data analysis [78]. Finally, the research team discussed and triangulated the derived template to secure validity [79].

\section{Results}

The findings of this paper provide insights into the processes that enable or hinder CG. First, we provide information on the role of leadership and institutional design, as this emerged as a critical factor for collaboration. Second, we explore the collaborative processes and initiatives from a stakeholder perspective and thereby highlight particular drivers and barriers of CG.

\subsection{Leadership for Collaborative Governance}

The findings highlight that leadership plays an essential role in facilitating and enabling collaboration in the case study destination (Table 4). The interviewees perceived leadership as a crucial but extremely challenging task. In this context, interviewees perceived different leadership styles. For example, an interviewee highlighted the organizing and managing role of leaders (Int.7, P.13). Other perceptions of leadership address a more visionary understanding, where decisions should be on the hand taken independently and on the other hand, in agreement with other stakeholders. In this context, an interviewee stated that visionary leadership also means to be disruptive and make decisions against the majority vote if necessary (Int.17, P.7). All interviewees perceived a responsibility to collaborate with other stakeholders in the destination. 
Table 4. Coding template.

\begin{tabular}{|c|c|}
\hline Category & Exemplary Quote \\
\hline \multicolumn{2}{|l|}{ Institutional Design } \\
\hline In/Exclusive Design & $\begin{array}{l}\text { Currently, there is no format where non-members can participate. We don't offer this but in my opinion, the people in the valley can already identify } \\
\text { with the tourism association and contact us with their requests. (...) We don't have a platform where people can attend meetings but this does not mean } \\
\text { that they don't know that we are there and that they don't drop by and request information. (Int.2, P.21) } \\
\text { I think that we could better engage with the local population. For example, topics such as transport policy because these topics are essential for locals } \\
\text { and tourism. In the end, such decisions must be beneficial for the locals as well. However, when it comes to marketing, we will continue to make the } \\
\text { decision alone (Int. 6, P.31). }\end{array}$ \\
\hline Configuration of Institutions & $\begin{array}{c}\text { At the moment, we don't have a strong DMO. There is a lot of insecurity in the region because the system, which prevailed before, was replaced a few } \\
\text { years ago and the new one is not established yet. (Int.9, P.28) } \\
\text { The local TAs don't trust the IDM and try to bundle decision-making capacity. However, the main problem is that they do not have the ability or the } \\
\text { interest to make decisions for the long run, but rather think about their community and the next season. (Int.9, P.28) }\end{array}$ \\
\hline Institution-business relationships & $\begin{array}{l}\text { I don' think that the IDM leaders engage a lot with hoteliers when making decisions, except for those who are part of the administrative board and who } \\
\text { theoretically have an advantage. We have connections to these hoteliers, therefore if we need something, we get in contact with them. (Int. 13, P.21) } \\
\text { The IDM is certainly far away. Although you have your networks where you know people, currently the IDM is too far away from the reality in the } \\
\text { market. (...) Now, the local tourism organizations are becoming more important again, especially for your individual business. There were certainly } \\
\text { times when the SMG had more contact with us. Now, the first contact person is certainly the local TA. (Int.11, P.18) }\end{array}$ \\
\hline \multicolumn{2}{|l|}{ Leadership } \\
\hline Responsibility & $\begin{array}{l}\text { I think the responsibility of a leader lies more in informing and sensitizing the community about the topics and in explaining the backgrounds and } \\
\text { considerations which have been made. (Int.7, P.13) } \\
\text { To make decisions above people's heads is very critical. Thus, it is very important to engage stakeholders and listen carefully to different opinions. } \\
\text { Stakeholders shouldn't be confronted with a fait accompli. Otherwise, they could refuse a decision simply because they had no possibility to state their } \\
\text { opinion. (Int.12, P.7) }\end{array}$ \\
\hline Setting values and inspiring & $\begin{array}{l}\text { I think in Meran we had many charismatic individuals who were able to promote numerous things. For example, think of the refurbishment of the } \\
\text { Kurhaus. The entire community was against it. Or think of the botanical gardens at Trauttmansdorff castle or the thermal baths in the city center of } \\
\text { Meran. These decisions were made against the consensus of the community by the former governor. He was a visionary. In my opinion, his decisions } \\
\text { saved the tourism in our destination. (Int.17, P.7) } \\
\text { I think it is important for leaders to promote clear ideas and values. At the moment this is only partially the case. I criticize that hoteliers, who are } \\
\text { involved in decision making, are often unable to make decisions for the long-run. They are very good in making decisions for the short-run. However, } \\
\text { from a tourism expert, I expect that he thinks about what will happen in the next } 50 \text { years. I miss that at the moment. I miss the long-term mentality, } \\
\text { but I expect it from people who have a say and contribute to the development of the destination. (Int.17, P.9) }\end{array}$ \\
\hline
\end{tabular}


Table 4. Cont.

\begin{tabular}{ccc}
\hline Category & Exemplary Quote \\
\hline Leadership & $\begin{array}{c}\text { Leaders should analyze the needs of all the industries in a destination, after all they have to consider everyone as important. However in the } \\
\text { implementation phase, you have to play hard and stay on this road, regardless of what may expect you. Otherwise you won't achieve anything. I think a } \\
\text { destination can only be successful if it has a clear vision and direction, even if it's not a suitable direction for everybody. (Int.15, P.5) } \\
\text { If a leader is certain about a topic, sometimes one has to make a decision also against the resistance of the community. Mostly because the superficial } \\
\text { assessment of the community can be dangerous. ( ... ) Of course, also leaders make mistakes but individuals of a community mostly see things only } \\
\text { from their own perspective without considering others. Also, a lack of know-how and missing background information play a key role. Hence, some } \\
\text { decisions have to be taken by leaders with the expertise and all the necessary information at hand. (Int.18, P.13) }\end{array}$ \\
\hline Lack of leadership & $\begin{array}{c}\text { It seems to me that we are leaderless at the moment. At the moment there is no one who knocks on the table and sets a direction. There is no one who } \\
\text { hits a line and has the courage to say how it should run. (Int.10, P.5) }\end{array}$ \\
I think that we need to consider South Tyrol and not just the Meranerland. I think corrections have to be made towards quality. I am currently missing \\
leading companies and executives. It is important to support the people who have it because we need these leading companies. (Int.10, P.17)
\end{tabular}

Note: IDM = central agency in charge of innovation, development, and marketing in South Tyrol (Italy); SMG = RTO that preceded the IDM; TA = tourism association. 
Often, interviewees were skeptical of local communities and residents' capabilities to handle engagement. An interviewee suggested that some decisions should be made based on experts' knowledge (Int. 18, P.13). In contrast, another interviewee explained that top-down decision making could result in problems for the destination, such as refusal of residents' support (Int.12, P.7). A common theme was that solutions and decisions should be suitable on a broad basis to be successful (Int.17, P.20). Additionally, interviewees highlighted the importance of stakeholder engagement. All leaders acknowledged the importance of engaging with stakeholders, but the timing differed significantly. While some interviewees were in favor of an open, collaborative process, others preferred to limit engagement to the consultation phase and to be rigid in the implementation phase (Int.15, P.5). Additionally, the interviewees highlighted that long-term orientation is a crucial feature of leadership (Int.17, P.9). In this context, varying leadership styles show different outcomes on the degree of collaboration. While some entrepreneurs involve and empower stakeholders, others are more oriented towards implementing actions without first establishing consensus.

\subsection{Institutional Design for Collaborative Governance}

The findings show that institutional transformation acts as a barrier to CG (Table 4). In the case study destination, insecurity emerged from changes in the governance setting. The existing institutions, responsible for tourism, were consolidated into a central agency that is responsible for innovation, product developments, communication, and marketing (IDM) and incorporated the responsibilities usually performed by DMOs. This central agency has three units to target the market with strategic business units instead of several DMOs. From a regional perspective, these changes helped to improve the market position of South Tyrol. However, on a local level, these changes led to insecurity and a loss of trust (Int.9, P.28). The changed institutional design resulted in increased insecurity that negatively affected the long-term planning of the destination. The newly established organization, which is responsible for managing the destination MeranerLand was perceived to be too far away and not yet fully effective. An interviewee explained that there is a lack of trust between the IDM (responsible for managing tourism-related activities) and local stakeholders. Although the transition was announced, some interviewees perceived the institutional change to be sudden, with negative effects for decision-making capabilities and resulting in short-term approaches to tourism strategy (Int.9, P.28).

In particular, the communication style of the newly established association (IDM) was criticized (Int.13, P.21). In summary, the interviews allow distilling two problems: First, the current communication style appears rather top-down but not surprising if it is considered how the new institutional design came into existence by a top government decision. Second, changing governance structures made responsibilities unclear and led to a lack of trust. Furthermore, local actors show strong awareness for the destination and want to be included in the decision-making process.

\subsection{Collaborative Governance Processes in Tourism}

The previous section highlighted the role of leadership and institutional settings for CG. However, deeper insights are necessary on a stakeholder level as interviewees indicated that collaborative processes differed for involved stakeholder groups (Table 5). It was found that face-to-face dialogue was an important theme for all stakeholder groups. Additionally, the interdependency between actors resulted in the need for shared understanding and trust-building. The interviews revealed that communication between entrepreneurs but also between DMOs and entrepreneurs frequently happens on an informal level and thereby highlighting the importance of face-to-face dialogue. An interviewee explained that this communication style also facilitates communication with local politicians,

"We nearly have daily meetings with the mayor and also with the council secretary. ( . . ) I know the mayor personally and we meet every day for coffee. If we have to discuss big and sensitive issues, we also join for formal meetings. We communicate very well and can count on his support, as he can count on ours." (Int.3, P.26) 
Table 5. Codes occurrence of collaborative governance on a stakeholder level.

\begin{tabular}{cccccc}
\hline Collaborative Processes & $\begin{array}{c}\text { DMO Level } \\
\mathbf{( \% )}\end{array}$ & $\begin{array}{c}\text { Public Body } \\
\text { Level (\%) }\end{array}$ & $\begin{array}{c}\text { Entrepreneurial } \\
\text { Level (\%) }\end{array}$ & $\begin{array}{c}\text { Local TA } \\
\text { Level (\%) }\end{array}$ & Total \\
\hline Face-to-face Dialogue & 23.81 & 38.46 & 30.77 & 40.91 & 23 \\
Shared Understanding & 28.57 & 15.38 & 7.69 & 18.18 & 13 \\
Trust-Building & 23.81 & 7.69 & 30.77 & 13.64 & 13 \\
Commitment to process & 9.52 & 15.38 & 23.08 & 13.64 & 10 \\
Intermediate Outcomes & 14.29 & 23.08 & 7.69 & 13.64 & 10 \\
number of documents & $5(25 \%)$ & $4(20 \%)$ & $7(35 \%)$ & $4(20 \%)$ & \\
\hline
\end{tabular}

However, communication at the destination level is not limited to the level of powerful actors. Other formats such as podium discussions and workshops were implemented to provide space for open discussions. The se meetings help to address antagonism between different parties such as businesses and local communities and help to reinforce mutual respect. However, open processes such as workshops can also lead to complicated situations. An interviewee explained,

"Sometimes it (workshops) makes things pretty complicated. It is interesting, but the more people have a say in a topic, the larger the variety of solutions. It results that all solutions need to be assessed. At that moment I have to take into account what others propose." (Int. 4, P.10)

Other issues of governance relate to the shared understanding of common goals and objectives. The findings showed that the shared understanding of goals represents an issue, especially on the level of entrepreneurs, where it is currently missing. Entrepreneurs strongly associated the formation of development trajectories with leadership tasks. In contrast, DMOs perceived the responsibility to act as leaders and to provide directions for future developments. Participation processes play an essential role to improve the shared understanding. An interviewee explained,

"It is very important to take stakeholders serious when making decisions that have effects on a large scale. When elaborating on the new plan for public transport, we provided everyone the opportunity to engage in this project. From people involved in tourism to elderly people, business people and young people, everyone had the opportunity and although it was a very tedious process, it was important because now we can implement it. ( ... ) I think it is our job to ask people what they want and then to decide. This differentiates our society from how it operated 20 years ago." (Int. 17, P.11)

Another central theme for all stakeholder groups was trust, which is often the legacy of past cooperation. It was found that entrepreneurs draw on strong local business networks, which help to establish trust between the different parties. The se networks help to maintain a trustworthy relationship between the actors. Findings showed that trust plays an important role for entrepreneurs and tourism organizations on the local level, which is supported by the presence of networks (Table 5). An interviewee mentioned,

“One cannot create economic or even entrepreneurial changes alone, so you always need others, these others are the network. Networks always have to do with trust and possibly also with a credit of trust. That means if I want to implement something new, I need the trust of people who support me. In order to tap into resources that I do not have myself, I need contacts with others and their trust." (Int.9, P.14)

Networks help to create an environment that improves trust and thereby enables collaborative decision-making. Nonetheless, interviewees referred to tensions that result from the attempt to exploit and manipulate relationships. For example, an interviewee noted that trust could be used to exert influence on decisions, 
"I had excellent connections to the political institutions that day. It only happened once that a decision was made against my advice and after a few phone calls with the governor the decision was revised. ( . . . ) However, the big advantage is that by having those connections and knowing people personally, you have bigger chances of being heard." (Int.10, P.9)

Relationships based on mutual trust are a powerful tool, but attention should be paid to the potential adverse and negative effects that could result from power asymmetries (Int. 10, P.9). The interviews showed that CG requires commitment from all parties involved. The findings highlight that mere declarations of interest are insufficient; rather, stakeholders and local communities demand commitment in the implementation phase. An interviewee explained,

"It is important to give all stakeholders the feeling of being involved. The refore, the discussed topics should also be implemented afterward. Otherwise, this can have negative consequences." (Int.1, P.34)

The findings highlighted that most interviewees are aware of their responsibility to collaborate with other stakeholders and to engage with others at different times in the development process. The interviewees noted that engaging with others is indispensable. An interviewee added,

"I think it is necessary to engage with the local residents. Tourism in the destination is reaching a level where many do not accept it anymore. For sure, some people benefit financially from tourism and they probably have a different opinion about tourism. However, tourism has an indirect effect on every individual in a destination. It will be impossible to ask everyone for his opinion, but in general leaders should listen to residents and make decisions not solely for touristic interests." (Int.19, P.9)

Leaders perceive themselves as stewards of the local population until the outcomes are favorable and as long as participation is limited to the consultation and design phase. A finding of the interviews is the actual negligence of local residents in tourism planning, although interviewees perceived a strong responsibility to integrate local residents in tourism planning. Small wins and joint achievements are important for CG. The success of CG is dependent on intermediate outcomes. The interviewees recognized that intermediate outcomes are important to ensure legitimacy and provide incentives for future participation in CG. Small gains strengthen trust-building between the stakeholders and facilitate collaborative actions. An interviewee explained,

"In tourism, the decisions have to be taken with regard to the entire community living in the destination. It doesn't matter if they are thin, thick, rich or poor. I have to select the solutions which are suitable for everyone. I shouldn't see things only from one perspective." (Int.17, P.20)

Furthermore, interviewees recognized that engaging with stakeholders has other benefits. For example, an interviewee noted that engagement with local actors could be a valuable source for the co-creation of new products and services. An interviewee explained,

"In the hotel industry, stakeholder engagement plays an important role. Due to the strong competition and quality in this region, you always try to implement new things. A few years ago, our business had a competitive advantage only due to new infrastructure. This is not the case anymore. Only good infrastructure is not enough. Hence, I think stakeholder engagement and interaction is very important because it is a great source of new ideas." (Int.12., P.9)

The interviewees highlighted several initiatives that provide positive intermediate outcomes for all stakeholders. For example, the local residents were invited to participate in the formulation of a new mobility plan for the public transport in the area of Merano. An online platform helped to show the initial plan and all local residents could participate in the further development of the plan. Another 
example is the implementation of a citywide complaint management system that encourages residents and visitors to submit complaints and critical observations. This offers stakeholders the opportunity to address current issues and serves as a pool for new ideas. The refore, based on the interview material and by using MAXQDA, the following drivers and barriers of CG in tourism were identified (Table 6).

Table 6. Drivers and barriers of collaborative governance.

\begin{tabular}{|c|c|c|}
\hline Drivers & Collaborative Processes & Barriers \\
\hline $\begin{array}{ll}\text { - } & \text { trustworthiness } \\
\text { - } & \text { support for ideas on a broad basis } \\
\text { - } & \text { appreciation to stakeholders } \\
\text { - } & \text { relationships and contacts } \\
\text { - } & \text { partnerships }\end{array}$ & Trust-Building & $\begin{array}{ll}\text { - } & \text { shortage of meetings } \\
\text { - } & \text { only formalized exchange } \\
\text { - } & \text { missing networks } \\
\text { - } & \text { low legitimacy } \\
\text { - } & \text { missing best practices } \\
\text { - } & \text { institutions withdrawal }\end{array}$ \\
\hline $\begin{array}{ll}\text { - } & \text { community orientation } \\
\text { - } & \text { open strategy formation process } \\
\text { - } & \text { common denominators } \\
\text { - } & \text { involvement of partners } \\
\text { - } & \text { cooperation across destinations } \\
\text { - } & \text { local strategy design }\end{array}$ & Shared Understanding & $\begin{array}{l}\text { - } \\
\text { strategy processes } \\
\text { - } \quad \text { a lack of round table sessions } \\
\text { for executives } \\
\text { - } \quad \text { responsibility shifted to others } \\
\text { - exclusion of non-touristic actors }\end{array}$ \\
\hline $\begin{array}{ll}\text { - } & \text { awareness creation } \\
\text { - } & \text { democratic principles } \\
\text { - } & \text { participatory inclusiveness } \\
\text { - } & \text { shared ownership of the strategy process } \\
\text { - } & \text { solidarity of involved actors }\end{array}$ & Commitment to process & $\begin{array}{l}\text { - } \quad \text { fait accompli } \\
\text { - } \quad \text { non-participation of stakeholders } \\
\text { - } \\
\text { - } \\
\text { chanances } \\
\text { focus on primary stakeholders }\end{array}$ \\
\hline $\begin{array}{l}\text { - } \quad \text { executive meetings and working groups } \\
\text { - } \quad \text { hablic forums, open spaces and town } \\
\text { - } \quad \text { networks with academics } \\
\text { - } \quad \text { discussions with business partners } \\
\text { - complaint management }\end{array}$ & Face-to-Face Dialogue & $\begin{array}{l}\text { - } \quad \text { missing personal communication } \\
\text { lack of cross- } \\
\text { institutional cooperation } \\
\text { time problems due to } \\
\text { business obligations } \\
\text { non-transparent forums } \\
\text { and meetings }\end{array}$ \\
\hline $\begin{array}{ll}\text { - } & \text { idea creation } \\
\text { - } & \text { infrastructure and service projects } \\
\text { - } & \text { online marketing and event platform } \\
\text { - } & \text { quality improvements } \\
\text { - } & \text { focus on sustainability and green events }\end{array}$ & Intermediate Outcomes & $\begin{array}{ll}\text { - } & \text { missing agreement with superior } \\
\text { - } & \text { public bodies } \\
\text { - } & \text { missing loyalty of actors } \\
\text { - } & \text { lack of policy integration }\end{array}$ \\
\hline
\end{tabular}

\section{Discussion}

Prior studies have noted the importance of collaboration as a process of joint decision making among autonomous, key stakeholders of an inter-organizational, community tourism domain to resolve planning problems of the domain and/or to manage issues related to the planning and development of the domain [20] (p. 188). The absence of systematic leadership, the lack of popular or elite consensus on the place of direct citizen participation, and the limited scope and powers of participatory innovation have been recognized as three major challenges for governance [35]. We found that leadership has a vital role in initiating and moderating collaborative processes. Previous literature highlighted two levels of leadership in tourism destinations: The first one addresses leadership within organizations and the second inter-organizational leadership, which refers to the situation where leadership is shared among a group of individuals that coordinate leadership tasks [27]. The network approach to leadership was also supported by the findings of Zehrer et al. [56] and Selin [17], who showed the importance of network-based leadership to manage destinations. Valente et al. [30] explored the role of leadership from a regional viewpoint on destinations and found that leadership can be "strong in some 
aspects and weak in others at the same time" [30] (p. 127). In this context, a lack of leadership exists in the case study destination on the regional level, where directions are currently missing because of the withdrawal of former institutions and bodies in charge of tourism planning (DMOs and SMG). Furthermore, the responsibilities for leadership tasks such as strategy development and the creation of an understanding for joint development trajectories were frequently shifted to other actors such as public bodies or the IDM.

The transformation of institutions had significant effects on the case study destination and potentially also on other destinations in South Tyrol, Italy. Following McLennan et al. [80], transformation theory offers an approach to understand the dynamic interaction between structure and institutions that occur when systems change. Institutions are essential competitiveness factors of destinations [6] and with some time lags, the transformation of the bodies responsible for tourism also affects the collaborative processes [80]. Surprisingly, none of the interviewees mentioned proactive strategies such as working groups or collaborative marketing strategies that came along with the transformation. Indeed, the findings showed that the transformation of the tourism institutions led to a perceived vacuum of leadership and a lack of trust on the local-regional level. This is diametral to the idea to make South Tyrol more competitive through the creation of strategic business units [70].

Another important theme is the powerful position of actors, which can result in adverse effects for CG [19]. Frequently, leaders who follow a command and control leadership style perceive issues when it comes to engagement in the implementation phase. This is the case if leaders restrict or inhibit the engagement of stakeholders in the decision-making process or if leaders manipulate the process because they have a coalition of interests. However, in the end, this leads to tensions with the community and decreases satisfaction. Social exchange theory [81] suggests that stakeholders should be provided with the opportunities to participate in decisions that affect their personal lives. Accordingly, preventing stakeholder engagement by not providing them the opportunity to interact with leaders and to have an impact on the decision process will not be feasible in the long-run. The interviewees highlighted contradicting opinions on how to engage with the local community and other stakeholders. Some interviewees referred to informative engagement strategies but others considered consultative engagement strategies and chose to consult stakeholders from time to time to get a better understanding of their interests [82]. Less often interviewees discussed decisional strategies to interact with stakeholders, such as to give them more formal roles and power by giving them the possibility to take part in the decision-making process. To be more specific, decisional participation was perceived to be complicated, although recent literature has shown that such decisions are more likely to be socially acceptable $[9,83]$. Another issue is the difficulty to find consensus in collaborative decision-making, which indicated that some decisions are not suitable to be taken by all stakeholders.

In the MeranerLand, several projects were realized, although the community was initially against it. Examples include the Kurhaus, the Terme Merano, or the Trauttmansdorff castle, which have developed into success stories and key assets of the region [71]. Interviewees associate these examples with visionary, charismatic leaders but are also aware that high levels of collaboration can be counterproductive if local communities are opposing development intentions. Finally, innovative forms of enabling stakeholder engagement have not spread to the case study destination. This may be the case because destination networks are often characterized by the closure to external actors [55] and thus interviewees believed that the existing networks are already highly open to other stakeholders. Furthermore, interviewees understood classical annual meetings as participatory and only a few examples referred to participatory workshops, discussions, or, e.g., technology support online platforms [60].

\section{Conclusions}

Ansell and Gash [19] concluded that time, trust, and interdependence are central for CG. In the tourism context, interdependency characterizes the industry and trust was perceived as an essential condition for collaboration by the interviewees. Destinations are maturing and seek to rejuvenate 
and thereby show the need for improved collaboration and inclusiveness [9]. The objective of this paper was to assess the underlying CG processes and to show the role of institutional design and leadership. For this reason, we conducted semi-guided interviews with key informants such as leading entrepreneurs, local tourism associations, public bodies, and regional destination management organizations (Table 2).

The findings highlight that leadership plays a crucial role in enabling collaborative processes in tourism. While strong leadership was present on the level of organizations and partly the destination level, the case study destination is lacking leadership on a regional level. This lack of leadership is partly due to the institutional change that occurred in South Tyrol (Italy) in the last years. Institutions were merged and new institutions took over the tasks, which were typically performed by DMOs and RTOs. The findings show that on a destination level, leadership was a major driver of CG that supported trust and communication among entrepreneurs and public body representatives. Findings indicate that leaders show strong commitment to collaborative processes because they are aware of the interdependence that characterizes the tourism industry. A barrier to CG is the lack of shared understanding among salient stakeholders [84].

Implications mainly target the communication between stakeholders. To receive critical feedback, stakeholders should continuously communicate with each other. In this context, DMOs and related institutions have an important role in moderating the process. For example, digitally supported platforms can be used to enable continuous interaction [60]. An important implication of this research is the necessity to strengthen the social embeddedness of newly entering entrepreneurs. Due to current market developments, new entrepreneurs and companies are entering community-oriented destinations. This creates the need to involve newly entering stakeholders into the current system that is strongly determined by social ties and embeddedness. Other implications target the design and execution of institutional transformation processes. More information should be provided to local communities, businesses, and public bodies upfront, and stronger support is necessary in the aftermath.

\section{Limitations and Future Research}

This study shows several limitations. The sample covers a broad spectrum of local entrepreneurs, tourism, and government officials that were understood to shape the destination's core services, strategic orientation, and innovation capability [53]. However, this study lacks a local community perspective, although many interviewees had double roles as residents and representatives. The qualitative case study design provides another limitation and more research is necessary to cross-validate the findings. In addition, the case study destination is in an autonomous region (South Tyrol, Italy) with special laws and regulations. Moreover, while collaborative processes are reasonably well advanced in established networks, more research is necessary to compare the effects of institutional transformation on governance networks and, ultimately, competitiveness [9,80]. Additionally, Nunkoo and Gursoy [85] called for more attention on power and trust as underlying components of tourism planning and there is definitely the need to shed more light on these phenomena in the CG context.

Author Contributions: This article is a joint work of the two authors. Conceptualization, B.F.B.; theory developing, B.F.B.; literature analysis, B.F.B.; empirical investigation, M.L.; data curation, M.L.; writing—original draft, B.F.B. and M.L.; writing-review and editing, B.F.B.; finding validation and discussion, B.F.B. and M.L.

Funding: This research received no external funding.

Acknowledgments: The authors would like to thank the University of Innsbruck for supporting this open access publication. It was published with financial support from the Vice Rectorate for Research of the University of Innsbruck.

Conflicts of Interest: The authors declare no conflict of interest.

\section{References}

1. Volgger, M.; Pechlaner, H. Governing networks in tourism: What have we achieved, what is still to be done and learned? Tour. Rev. 2015, 70, 298-312. [CrossRef] 
2. Ruhanen, L.; Scott, N.; Ritchie, B.W.; Tkaczynski, A. Governance: A review and synthesis of the literature. Tour. Rev. 2010, 65, 4-16. [CrossRef]

3. Borges, M.d.R.; Eusébio, C.; Carvalho, N. Governance for sustainable tourism: A review and directions for future research. Eur. J. Tour. Res. 2014, 45-56.

4. Stoffelen, A.; Ioannides, D.; Vanneste, D. Obstacles to achieving cross-border tourism governance: A multi-scalar approach focusing on the German-Czech borderlands. Ann. Tour. Res. 2017, 64, 126-138. [CrossRef]

5. Peters, M.; Strobl, A. Toward a theory of destination governance. In Contemporary Destination Governance: A Case Study Approach, 1st ed.; Pechlaner, H., Beritelli, P., Pichler, S., Peters, M., Scott, N., Eds.; Emerald Books: Bingley, UK, 2015; pp. 23-232; ISBN 9781783501120.

6. Volgger, M.; Pechlaner, H. Requirements for destination management organizations in destination governance: Understanding DMO success. Tour. Manag. 2014, 41, 64-75. [CrossRef]

7. Al-Najjar, B. Corporate governance, tourism growth and firm performance: Evidence from publicly listed tourism firms in five Middle Eastern countries. Tour. Manag. 2014, 42, 342-351. [CrossRef]

8. Erkuş-Öztürk, H.; Eraydın, A. Environmental governance for sustainable tourism development: Collaborative networks and organisation building in the Antalya tourism region. Tour. Manag. 2010, 31, 113-124. [CrossRef]

9. Bichler, B.F. Designing tourism governance: The role of local residents. J. Destin. Manag. Mark. 2019. [CrossRef]

10. Nelson, L.S.; Robbins, M.D.; Simonsen, B. Introduction to the Special Issue on Governance. Soc. Sci. J. 1998, 35, 477-491. [CrossRef]

11. Beaumont, N.; Dredge, D. Local tourism governance: A comparison of three network approaches. J. Sustain. Tour. 2010, 18, 7-28. [CrossRef]

12. van der Zee, E.; Gerrets, A.-M.; Vanneste, D. Complexity in the governance of tourism networks: Balancing between external pressure and internal expectations. J. Destin. Manag. Mark. 2017, 6, 296-308. [CrossRef]

13. Baggio, R.; Cooper, C. Knowledge transfer in a tourism destination: The effects of a network structure. Serv. Ind. J. 2010, 30, 1757-1771. [CrossRef]

14. Keyim, P. Tourism collaborative governance and rural community development in Finland: The case of Vuonislahti. J. Travel Res. 2017, 57, 483-494. [CrossRef]

15. Jamal, T.B.; Watt, E.M. Climate change pedagogy and performative action: Toward community-based destination governance. J. Sustain. Tour. 2011, 19, 571-588. [CrossRef]

16. Bets, L.; Lamers, M.; Tatenhove, J. Collective self-governance in a marine community: Expedition cruise tourism at Svalbard. J. Sustain. Tour. 2017, 25, 1583-1599. [CrossRef]

17. Selin, S. Elaborating the role of backbone leadership organizations in sustainable tourism development: The Monongahela River valley coalition. Sustainability 2017, 9, 1367. [CrossRef]

18. Keyim, P. Tourism and rural development in western China: A case from Turpan. Community Dev. J. 2016, 51, 534-551. [CrossRef]

19. Ansell, C.; Gash, A. Collaborative governance in theory and practice. J. Public Adm. Res. The ory 2007, 18, 543-571. [CrossRef]

20. Jamal, T.B.; Getz, D. Collaboration theory and community tourism planning. Ann. Tour. Res. 1995, 22, 186-204. [CrossRef]

21. Mustakallio, M.; Autio, E.; Zahra, S.A. Relational and contractual governance in family firms: Effects on strategic decision making. Fam. Bus. Rev. 2002, 15, 205-222. [CrossRef]

22. Beritelli, P.; Bieger, T.; Laesser, C. Destination governance: Using corporate governance theories as a foundation for effective destination management. J. Travel Res. 2007, 46, 96-107. [CrossRef]

23. Gill, A.M.; Williams, P.W. Rethinking resort growth: Understanding evolving governance strategies in Whistler, British Columbia. J. Sustain. Tour. 2011, 19, 629-648. [CrossRef]

24. Strobl, A.; Peters, M. Entrepreneurial reputation in destination networks. Ann. Tour. Res. 2013, 40, 59-82. [CrossRef]

25. Mandell, M.; Keast, R. Evaluating network arrangements: Toward revised performance measures. Public Perform. Manag. 2007, 30, 574-597. [CrossRef]

26. Hall, C.M. A typology of governance and its implications for tourism policy analysis. J. Sustain. Tour. 2011, 19, 437-457. [CrossRef] 
27. Beritelli, P.; Bieger, T. From destination governance to destination leadership—Defining and exploring the significance with the help of a systemic perspective. Tour. Rev. 2014, 69, 25-46. [CrossRef]

28. Bramwell, B.; Lane, B. Critical research on the governance of tourism and sustainability. J. Sustain. Tour. 2011, 19, 411-421. [CrossRef]

29. Presenza, A.; Abbate, T.; Micera, R. The Cittaslow movement: Opportunities and challenges for the governance of tourism destinations. Tour. Plan. Dev. 2015, 12, 479-488. [CrossRef]

30. Valente, F.; Dredge, D.; Lohmann, G. Leadership and governance in regional tourism. J. Destin. Manag. Mark. 2015, 4, 127-136. [CrossRef]

31. Bramwell, B.; Sharman, A. Collaboration in local tourism policymaking. Ann. Tour. Res. 1999, 26, $392-415$. [CrossRef]

32. Bramwell, B. Governance, the state and sustainable tourism: A political economy approach. J. Sustain. Tour. 2011, 19, 459-477. [CrossRef]

33. Wagner, O.; Peters, M. Can association methods reveal the effects of internal branding on tourism destination stakeholders? J. Place Manag. Dev. 2009, 2, 52-69. [CrossRef]

34. Garrod, B.; Fyall, A.; Leask, A.; Reid, E. Engaging residents as stakeholders of the visitor attraction. Tour. Manag. 2012, 33, 1159-1173. [CrossRef]

35. Fung, A. Putting the public back into governance: The challenges of citizen participation and its future. Public Adm. Rev. 2015, 75, 513-522. [CrossRef]

36. Emerson, K.; Nabatchi, T.; Balogh, S. An integrative framework for collaborative governance. Public Adm. Rev. 2012, 22, 1-29. [CrossRef]

37. David, R.J.; Han, S.-K. A systematic assessment of the empirical support for transaction cost economics. Strateg. Manag. J. 2004, 25, 39-58. [CrossRef]

38. Vignieri, V. Destination governance at stake: Fostering policy coordination among decision-makers of a small town. Tour. Plan. Dev. 2019, 16, 556-574. [CrossRef]

39. Gyimóthy, S.; Meged, J.W. The Camøno: A communitarian walking trail in the sharing economy. Tour. Plan. Dev. 2018, 15, 496-515. [CrossRef]

40. Dragouni, M.; Fouseki, K. Drivers of community participation in heritage tourism planning: An empirical investigation. J. Herit. Tour. 2018, 13, 237-256. [CrossRef]

41. Charlie, C.; King, B.; Pearlman, M. The Application of Environmental Governance Networks in Small Island Destinations: Evidence from Indonesia and the Coral Triangle. Tour. Plan. Dev. 2013, 10, 17-31. [CrossRef]

42. Zeppel, H. Collaborative governance for low-carbon tourism: Climate change initiatives by Australian tourism agencies. Curr. Issues Tour. 2012, 15, 603-626. [CrossRef]

43. Robertson, P.J. An assessment of collaborative governance in a network for sustainable tourism: The case of RedeTuris. J. Public Adm. 2011, 34, 279-290. [CrossRef]

44. Hanleybrown, F.; Kania, J.; Kramer, M. Channeling change: Making collective impact work. Stanf. Soc. Innov. Rev. 2012, 10, 1-9.

45. Slocum, S.L.; Everett, S. Industry, government, and community: Power and leadership in a resource constrained DMO. Tour. Rev. 2014, 69, 47-58. [CrossRef]

46. Hall, C.M. Politics and place: An analysis of power in tourism communities. In Tourism in Destination Communities; Singh, S., Timothy, D.J., Dowling, R.K., Eds.; Cabi Pub: Oxon, UK; Cambridge, MA, USA, 2003; pp. 99-113; ISBN 9780851996110.

47. Khazaei, A.; Elliot, S.; Joppe, M. An application of stakeholder theory to advance community participation in tourism planning: The case for engaging immigrants as fringe stakeholders. J. Sustain. Tour. 2015, 23, 1049-1062. [CrossRef]

48. Tosun, C. Expected nature of community participation in tourism development. Tour. Manag. 2006, 27, 493-504. [CrossRef]

49. Lin, D.; Simmons, D. Structured inter-network collaboration: Public participation in tourism planning in Southern China. Tour. Manag. 2017, 63, 315-328. [CrossRef]

50. Beritelli, P. Cooperation among prominent actors in a tourist destination. Ann. Tour. Res. 2011, 38, 607-629. [CrossRef]

51. Pechlaner, H.; Volgger, M. How to promote cooperation in the hospitality industry: Generating practitioner-relevant knowledge using the GABEK qualitative research strategy. Int. J. Contemp. Hosp. Manag. 2012, 24, 925-945. [CrossRef] 
52. Pechlaner, H.; Kozak, M.; Volgger, M. Destination leadership: A new paradigm for tourist destinations? Tour. Rev. 2014, 69, 1-9. [CrossRef]

53. Koh, K.Y. Understanding community tourism entrepreneurism. In Tourism and Sustainable Community Development; Richards, G., Hall, D., Eds.; Routledge: London, UK, 2003; pp. 205-217; ISBN 0415309158.

54. Hoppe, B.; Reinelt, C. Social network analysis and the evaluation of leadership networks. T. Leadersh. Quart. 2010, 21, 600-619. [CrossRef]

55. Beritelli, P.; Strobl, A.; Peters, M. Interlocking directorships against community closure: A trade-off for development in tourist destinations. Tour. Rev. 2013, 68, 21-34. [CrossRef]

56. Zehrer, A.; Raich, F.; Siller, H.; Tschiderer, F. Leadership networks in destinations. Tour. Rev. 2014, 69, 59-73. [CrossRef]

57. Pearce, D. Tourist Organizations; Longman Scientific \& Technical: Harlow, UK, 1992; ISBN 9780582070103.

58. Nordin, S.; Volgger, M.; Gill, A.; Pechlaner, H. Destination governance transitions in skiing destinations: A perspective on resortisation. Tour. Manag. Perspect. 2019, 31, 24-37. [CrossRef]

59. Hall, D.R. Tourism and Transition. Governance, Transformation and Development; CABI: Wallingford, UK, 2004; ISBN 9780851997483.

60. Lalicic, L. Open innovation platforms in tourism: How do stakeholders engage and reach consensus? Int. J. Contemp. Hosp. Manag. 2018, 30, 2517-2536. [CrossRef]

61. Dredge, D.; Whitford, M. Event tourism governance and the public sphere. J. Sustain. Tour. 2011, 19, 479-499. [CrossRef]

62. Denzin, N.K.; Lincoln, Y. (Eds.) The SAGE Handbook of Qualitative Research, 4th ed.; Thousand Oaks: Los Angeles, CA, USA, 2011; ISBN 9781412974172.

63. Phillimore, J.; Goodson, L. (Eds.) Qualitative Research in Tourism. Ontologies, Epistemologies and Methodologies; Routledge: London, UK; New York, NY, USA, 2004; ISBN 0415280877.

64. Dredge, D. Policy networks and the local organisation of tourism. Tour. Manag. 2006, 27, 269-280. [CrossRef]

65. O'Mahoney, J.; Vincent, S. Critical Realism as an Empirical Project a Beginner's Guide. In Studying Organizations Using Critical Realism: A Practical Guide; Edwards, P.K., Ed.; Oxford Univ. Press: Oxford, UK, 2014; pp. 1-20; ISBN 9780199665525.

66. Flyvberg, B. Case study. In The SAGE Handbook of Qualitative Research, 4th ed.; Denzin, N.K., Lincoln, Y., Eds.; Thousand Oaks: Los Angeles, CA, USA, 2011; pp. 301-316; ISBN 9781412974172.

67. Eisenhardt, K.M. Building theories from case study research. Acad. Manag. Rev. 1989, 14, 532-550. [CrossRef]

68. MGM. Marketinggesellschaft Meran: Abschlussbericht. Available online: http://mgm.bz.it/fileadmin/user_ upload/documents/pdf/MGM_Jahresbericht_2017_SCREEN_DEF.pdf (accessed on 31 May 2019).

69. IDM South Tyrol. Das war 2018: Tätigkeitsbericht. Available online: https://www.idm-suedtirol.com/de/ publikationen/20-das-war-2018.html (accessed on 31 May 2019).

70. Beritelli, P.; Bieger, T.; Laesser, C. The new frontiers of destination management. J. Travel Res. 2014, 53, 403-417. [CrossRef]

71. IDM South Tyrol. MeranerLand: Alpin-Mediterranes Lebensgefühl. Available online: https://www.meranosuedtirol.it/de/meraner-land.html (accessed on 21 October 2019).

72. Aguinis, H.; Solarino, A.M. Transparency and replicability in qualitative research: The case of interviews with elite informants. Strateg. Manag. J. 2019, 40, 1291-1315. [CrossRef]

73. Gobo, G. Sampling, representativeness and generalizability. In Qualitative Research Practice; Reprinted; Seale, C., Gobo, G., Gubrium, J.F., Eds.; Sage: London, UK, 2005; pp. 435-455; ISBN 0761947760.

74. Alasuutari, P. Researching Culture. Qualitative Method and Cultural Studies; Sage: London, UK, 1995; ISBN 0803978316.

75. Tuohino, A.; Konu, H. Local stakeholders' views about destination management: Who are leading tourism development? Tour. Rev. 2014, 69, 202-215. [CrossRef]

76. King, N. Doing template analysis. In Qualitative Organizational Research: Core Methods and Current Challenges, 1st ed.; Symon, G., Cassell, C., Eds.; Sage: Los Angeles, CA, USA, 2012; pp. 426-449; ISBN 9780857024107.

77. Crabtree, B.F.; Miller, W.F. A template approach to text analysis: Developing and using codebooks. In Doing Qualitative Research, 3rd ed.; Crabtree, B.F., Miller, W.F., Eds.; SAGE Publications Inc.: Thousand Oaks, CA, USA, 1992; pp. 93-109. 
78. King, N.; Horrocks, C.; Brooks, J.M. Interviews in Qualitative Research, 2nd ed.; Sage: Los Angeles, CA, USA; London, UK; New Delhi, India; Singapore; Washington, DC, USA; Melbourne, Australia, 2019; ISBN 9781446274972.

79. Decrop, A. Triangulation in qualitative tourism research. Tour. Manag. 1999, 20, 157-161. [CrossRef]

80. McLennan, C.-L.; Ruhanen, L.; Ritchie, B.; Pham, T. Dynamics of destination development. J. Hosp. Tour. Res. 2012, 36, 164-190. [CrossRef]

81. Ap, J. Residents' perceptions on tourism impacts. Ann. Tour. Res. 1992, 19, 665-690. [CrossRef]

82. Arnstein, S.R. A ladder of citizen participation. J. Am. Inst. Plan. 1969, 35, 216-224. [CrossRef]

83. Green, A.O.; Hunton-Clarke, L. A typology of stakeholder participation for company environmental decision-making. Bus. Strategy Environ. 2003, 12, 292-299. [CrossRef]

84. Sheehan, L.R.; Ritchie, B.J.R. Destination stakeholders exploring identity and salience. Ann. Tour. Res. 2005, 32, 711-734. [CrossRef]

85. Nunkoo, R.; Gursoy, D. Rethinking the role of power and trust in tourism planning. J. Hosp. Mark. Manag. 2016, 25, 512-522. [CrossRef]

(C) 2019 by the authors. Licensee MDPI, Basel, Switzerland. This article is an open access article distributed under the terms and conditions of the Creative Commons Attribution (CC BY) license (http://creativecommons.org/licenses/by/4.0/). 